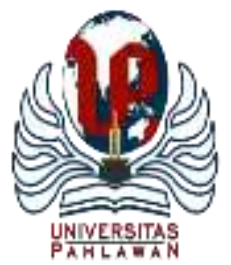

Edukatif : Jurnal Ilmu Pendidikan Volume 3 Nomor 6 Tahun 2021 Halm 4329 - 4339

EDUKATIF: JURNAL ILMU PENDIDIKAN

Research \& Learning in Education

https:/ledukatif.org/index.php/edukatif/index

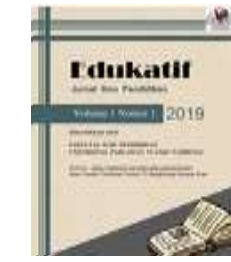

\title{
Refleksi Pemikiran Pembaharuan Pendidikan Islam Kh. Ahmad Dahlan terhadap Problematika Pendidikan Islam
}

Ghufran Hasyim Achmad

UIN SunanKalijaga Yogyakarta, Indonesia

E-mail : ghufrandjeri@gmail.com

\begin{abstract}
Abstrak
Problematika pendidikan Islam saat ini sangat kompleks. Problematika tersebut terkait dengan sistem pendidikan, sistem pembelajaran, sampai kepada kualitas output lembaga pendidikan Islam. KH. Ahmad Dahlan merupakan salah satu tokoh yang berperan dalam melakukan pembaharuan pendidikan Islam khususnya di Indonesia. Sehingga penelitian bertujuan untuk menganalisis bagaimana pemikiran serta pergerakan KH. Ahmad Dahlan sebagai tokoh pembaharuan pendidikan, serta menjadikannya sebagai refleksi bagi lembaga pendidikan dalam menyikapi problematika yang sedang dihadapi. Penelitian ini dilakukan dengan metode penelitian kepustakaan (library research). Berdasarkan analisis dari sumber data, maka dapat disimpulkan bahwa KH. Ahmad Dahlan melakukan pembaharuan terkait dengan tujuan pendidikan, materi dan metode pembelajaran, dan sistem pendidikan. Pemikiran KH. Ahmad Dahlan sangat relevan sebagai refleksi bagi lembaga pendidikan Islam dalam menyikapi berbagai problematika yang dihadapi. Penerapan pemikiran KH. Ahmad Dahlan dapat meningkatkan kualitas lembaga pendidikan Islam. Dengan demikian akan lahir output lembaga pendidikan Islam yang berjiwa sosial, nasionalisme, serta berjiwa religius yang tinggi.
\end{abstract}

Kata Kunci: Pemikiran, Pendidikan Islam, KH. Ahmad Dahlan

\begin{abstract}
The problems of Islamic education today are very complex. These problems are related to the education system, the learning system, to the quality of the output of Islamic educational institutions. KH. Ahmad Dahlan is one of the figures who play a role in reforming Islamic education, especially in Indonesia. So the research aims to analyze how the thoughts and movements of KH. Ahmad Dahlan as a figure of educational reform, as well as making it a reflection for educational institutions in addressing the problems being faced. This research was conducted using library research methods. Based on the analysis of the data sources, it can be concluded that KH. Ahmad Dahlan made reforms related to educational goals, learning materials and methods, and the education system. Thoughts KH. Ahmad Dahlan is very relevant as a reflection for Islamic educational institutions in addressing the various problems faced. The application of thingking's KH. Ahmad Dahlan can improve the quality of Islamic educational institutions. Thus, the output of Islamic educational institutions with a social spirit, nationalism, and a high religious spirit will be born.
\end{abstract}

Keywords: Thought, Islamic Education, KH. Ahmad Dahlan

Copyright (c) 2021 Ghufran Hasyim Achmad

$\triangle$ Corresponding author

Email : ghufrandjeri@gmail.com

DOI : https://doi.org/10.31004/edukatif.v3i6.1319

ISSN 2656-8063 (Media Cetak)

ISSN 2656-8071 (Media Online) 
4330 Refleksi Pemikiran Pembaharuan Pendidikan Islam Kh. Ahmad Dahlan terhadap Problematika Pendidikan Islam - Ghufran Hasyim Achmad

DOI: https://doi.org/10.31004/edukatif.v3i6.1319

\section{PENDAHULUAN}

Pada pergantian abad kedua puluh, pendidikan Islam terpecah menjadi komponen agama dan sekuler. Bahwa dengan realita yang terjadi terdapat pendikotomian ilmu pengetahuan lembaga Pendidikan Islam yang secara faktual tidak melakukan proses internalisasi pengetahuan umum dalam kurikulum pembelajarannya, dan sebaliknya bagi lembaga pendidikan umum yang tidak mengintegrasikan pendidikan agama kedalam kurikulum pembelajaran. Terlebih, output yang terbangun dari hasil pembelajaran di lembaga pendidikan tersebur (Lembaga Pendidikan islam/umum), tidak memiliki impact yang jelas untuk pengembangan masyarakat. Pendidikan sekolah Belanda seakan menjauhkan pribumi dari budayanya. Hal ini dikarenkan pendidikan Belanda pada masa itu menanamkan kepada siswa dengan konsep nederlandcentris. Maka pribumi meninggalkan, melupakan budayanya dan menggaungkan budaya Belanda atau Barat. Dan juga pendidikan Barat atau Belanda bersifat sekuler yang tidak memasukan ilmu agama kepada anak-anak sehingga Islam dinilai negatif dan tertinggal.

Kondisi pendidikan khususnya pendidikan Islam di Indonesia saat itu dapat dikatakan sangat terpuruk. Hal tersebut yang mendorong KH. Ahmad Dahlan untuk melakukan gerakan pembaharuan. Pemikiran dan pergerakan yang dilakukan oleh KH. Ahmad Dahlan berpengaruh besar terhadap perkembangan pendidikan Islam di Indonesia.KH. Ahmad Dahlan berusaha menjawab berbagai macam persoalan yang dihadapi oleh pendidikan Islam saat itu.

Pembaharuan pendidikan yang dilakukan KH. Ahmad Dahlan dapat dikatakan sebagai salah satu bentuk gerakan awal kebangkitan pendidikan Islam di Indonesia. Meskipun pada awal pergerakannya mendapat tantangan dari lingkungan pendidikan tradisional, KH. Ahmad Dahlan tetap optimis melakukan gerakan pembaharuan. Tantangan yang dihadapai oleh beliau dihadapi dengan arif dan bijaksana. Sikap yang demikian menjadikan pemikiran dan gerakan pembaharuan KH. Ahmad Dahlan dapat diterima oleh masyarakat umum (Putra, 2018).

Pemikiran KH.Ahmad Dahlan seharusnya dapat menjadi refleksi dalam menyikapi berbagai problematika pendidikan Islam di Indonesia dewasa ini. Beberapa problematika yang dihadapi oleh pendidikan Islam dewasa ini seperti masih adanya sikap dikotomis antara ilmu agama dan ilmu umum. KH. Ahmad Dahlan menganjurkan agar pendidikan umum dimasukkan dalam kurikulum madrasah (Nata, 2005). Anjuran tersebut menunjukkan bahwa beliau tidak mendikotomi antara ilmu agama dan ilmu umum. Karena sikap dikotomis tersebut dapat menjadikan pendidikan Islam apatis terhadap Sains. Meskipun demikian, sampai saat ini masih ada masyarakat yang mendiskreditkan salah satu dari kedua term tersebut. Padahal Islam tidak membatasi untuk mendalami ilmu pengetahuan selama pengetahuan tersebut berdampak positif.

Problematika lain ada ditengah-tengah pendidikan Islam adalah metode pembelajaran. Banyak lembaga pendidikan Islam yang masih menggunakan pendekatan teksutal dalam proses pembelajaran. Hal tersebut dapat menjadikan pendidikan Islam terkesan tidak peka dengan realitas sosial. Terutama Indonesia yang merupakan negara dengan masyarakat yang multikultural. Masyarakat Indonesia memiliki beragam agama, budaya, dan ras. Bahkan kaitannya dengan perbedaaan agama, banyak terjadi kasus kesenjangan sosial antar pemeluk agama. Hal ini terjadi karena kurangnya sikap toleransi yang dimiliki oleh setiap pemeluk agama. Pendidikan Islam harus mampu menanamkan nilai-nilai toleransi kepada peserta didik. Berdasarkan berbagai problematika tersebut, penelitian dilakukan untuk mengetahui bagaimana pemikiran dan pergerakan $\mathrm{KH}$. Ahmad Dahlan terkait pembaharuan pendidikan Islam, kemudian dapat menjadikan pemikiran dan pergerakan beliau sebagai refleksi dalam menyikapi berbagai prolematika pendidikan Islam dewasa ini. 
4331 Refleksi Pemikiran Pembaharuan Pendidikan Islam Kh. Ahmad Dahlan terhadap Problematika Pendidikan Islam - Ghufran Hasyim Achmad

DOI: https://doi.org/10.31004/edukatif.v3i6.1319

\section{METODE PENELITIAN}

Dalam penelitian ini merupakan upaya untuk menggali dan mengkaji secara kritis mengenai pembaharuan pemikiran KH. Ahmad Dahlan dan pendidikan Islam di Indonesia. Kajian ini merupakan hasil penelitian dengan metode penelitian kepustakaan (library research). Penelitian ini tidak perlu terjuan ke lapangan, tapi cukup memanfaatkan dari beberapa sumber kepustakaan sebagai sumber data penelitian (Hamzah, 2020). Penelitian dilakukan dalam beberapa tahap. Tahap pertama, pencarian data yang bersumber dari buku, jurnal, ataupun artikel ilmiah yang berkaitan dengan topik pembahasan. Buku yang digunakan sebagai rujukan adalah buku yang membahas biografi, pemikiran, sarta pergerakan KH. Ahmad Dahlan yang berjumlah 13 buku. Sedangkan jurnal dan artkel ilmiah dipilih sebagai rujukan beradasarkan reputasi jurnal maupun penerbit artikel. Pemilihan jurnal dan artikel bereputasi demi menjamin kualitas sumber data yang akan dinalisis.

Tahap kedua adalah analisis data. Analisis data dilakukan dengan metode analisis isi. Metode ini dilakukan dengan cara mengidentifikasi informasi secara objektif dan sistematis. Tahap ketiga adalah penarikan kesimpulan. Berdasarkan tujuan metode analisis isi adalah untuk menguraikan dan menyimpulkan data atau informasi yang ditemukan. Maka setelah data dianalisis, kemudian dibuatkan simpulan dari hasil analisis data tersebut (Hamzah, 2020).

\section{HASIL DAN PEMBAHASAN PENELITIAN}

Penelitian sebelumnya mengenai KH. Ahmad Dahlan seperti yang dilakukan oleh Amelia dan Hudaidah terfokus kepada analisis pemikiran dan pergerakan, seperti pembentukan Organisasi Muhammadiyah dan Aisyiah (Amelia \& Hudaidah, 2021). Kemudian penelitian lain juga seperti yang dilakukan oleh Putra, hanya terfokus kepada konsep pendidikan perspektif KH. Ahmad Dahlan (Putra, 2018). Selain itu, penelitian yang dilakukan oleh Syaifuddin, Anggraeni, Khotimah, dan Mahfud terfokus kepada sejarah Muhammadiyah (Syaifuddin et al., 2019). Sehingga penulis mengelaborasi baik itu dari biografi KH. Ahmad Dahlan, pemikiran dan pergerakan, serta refleksi dari pemikiran dan pergerakan beliau bagi dunia pendidikan khususnya pendidikan Islam dalam menyikapi problematika yang sedang dihadapi.

KH. Ahmad Dahlan lahir pada tahun 1868 di Kauman Yogyakarta dan meninggal pada tanggal 25 Februari 1923 di Yogyakarta dalam usia 55 tahun (Mu'thi \& Marihandono, 2015). KH. Ahmad Dahlan berasal dari keluarga yang taat dan terkenal karena ketakwaannya dalam urusan agama. Beliau adalah putra dari KH. Abu Bakar yang menjadi imam dan khatib di Masjid Besar Keraton Yogyakarta. KH. Abu Bakar adalah keturunan kedua belas dari Maulana Malik Ibrahim, seorang Walisongo terkemuka. Ibu KH. Ahmad Dahlan bernama Siti Aminah. Beliau adalah putri dari KH Ibrahim, mantan penguasa Keraton Yogyakarta.(Muvid, 2020)

KH. Ahmad Dahlan sejak kecil dibesarkan dan disekolahkan sebagai anak seorang Kyai. Pendidikan dasar beliau dimulai dengan pembelajaran yang difokuskan kedalam persolan mengkaji Al-Qur'an secara matang, dan begitu pula dengan teks-teks agama Islam lainnya. Dalam pendidikan formal, KH. Ahmad Dahlan belajar di Lembaga Pendidikan Dasar. Lembaga tersebut merupakan sekolah yang didirikan langsung oleh Ayahnya. Setelah beranjak dewasa, KH. Ahmad Dahlan memulai aktivitas intelektualnya dengan meneliti dan memajukan ilmu agama yang dibantu oleh beberapa intelektual besar pada zamannya, diantaranya: KH. Muhammad Saleh (ilmu fiqih), KH. Muhsin (Ilmu nahwu), KH. R. Dahlan (ilmu falak), KH. Mhfudz \& Syekh Khayyat Sattokh (ilmu hadist), Syekh Amin \& Syekh Bakri (qira'at Al-Qur'an). Serta beberapa guru lainnya. Berdasarkan lingkungan dan aktivitas menuntut ilmu yang demikian, tidak mengherankan bahwa beliau dapat mempelajari berbagai disiplin ilmu Islam pada usia dini. Dan karakteristik dari KH. Ahmad Dahlan yang sangat haus akan ilmu, segala jenis ilmu yang beliau dapatkan dari gurunya tersebut, akan selalu ia cari lebih dalam (Ramayulis \& Nizar, 2010). 
4332 Refleksi Pemikiran Pembaharuan Pendidikan Islam Kh. Ahmad Dahlan terhadap Problematika Pendidikan Islam - Ghufran Hasyim Achmad

DOI: https://doi.org/10.31004/edukatif.v3i6.1319

Pada tahun 1890, setelah beberapa bulan belajar kepada para gurunya, KH. Ahmad Dahlan melakukan perjalanan ke Mekah selama satu tahun untuk belajar ilmu keislaman. Setelah satu tahun belajar, beliau pulang ke Indonesia. Akan tetapi, beliau mengklaim bahwa beliau tidak puas dengan pemahamannya sebelumnya. Sehingga, kira-kira tahun 1903 KH. Ahmad Dahlan kembali ke Mekah, dan tinggal disana selama dua tahun untuk kembali belajar. Beliau bertemu dengan beberapa cendekiawan Indonesia di Mekkah pada masa itu, seperti Syekh Muhammad Khatib al-Minangkabaw, Kyai Nawawi al-Banteni, Kyai Mas Abdullah, dan Kyai Faqih Kembang.

Pada periode yang sama, KH. Ahmad Dahlan mengenal konsep pembaharuan Islam dengan meneliti karya-karya para ulama pendahulu seperti karya dari Muhammad Abduh, Rashid Ridha dan yang lainnya.(Nizar, 2005)KH. Ahmad Dahlan dimotivasi oleh pandangan para reformis. KH. Ahmad Dahlan bertugas mengimplementasikan perubahan di Indonesia. Meskipun KH. Ahmad Dahlan pernah belajar secara pribadi dengan Abduh dan Rasyid Rida, ia terinspirasi dari peremajaan mereka dengan membaca tulisantulisan mereka.

Setelah menempuh perjalanan intelektual dan spiritual yang Panjang dari Mekah, KH. Ahmad Dahlan menikah dengan Siti Walidah, seorang anak pak Kyai Fadhil dan masih kerabat dekatnya juga. Istri dari KH. Ahmad Dahlan, dikenal sebagai Nyai Ahmad Dahlan, atau yang sering kita kenal sebagai pahlawan nasional dan pendiri Aisyah. KH. Ahmad Dahlan memiliki enam anak dari pernikahannya dengan Siti Walidah: Djohanah, Siradj Dahlan, Siti Busyro, Irfan Dahlan, Siti Aisyah, dan Siti Zahara (Basri, 2009).

KH. Ahmad Dahlan juga seorang saudagar batik selain mengajar kegiatan keagamaan. Selain itu, ia adalah anggota aktif dari berbagai organisasi. Sikapnya yang ramah, sabar, dan reseptif membuatnya menjadi sosok yang populer di antara berbagai kelompok politik. Ia bahkan bertemu dan berbincang dengan seorang pendeta Katolik bernama Van Lith.

KH. Ahmad Dahlan secara khusus banyak mengadopsi pemikiran dengan gagasan regenerasi yang berkembang di Timur Tengah, terutama jika melihat dinamika statis umat Islam Indonesia. Alhasil, sekembalinya ke kampung halaman, ia sangat aktif menggalakkan konsep regenerasi ke seluruh pelosok tanah air. Hubungan KH. Ahmad Dahlan dengan tokoh-tokoh pergerakan di tanah air, seperti Budi Utomo dan Serikat Islam (SI) yang dididik di barat, serta pembaruan Islam di daerah lain, sangat mempengaruhi pandangannya tentang relevansi modernisme. Upayanya antara lain penerimaan selektif terhadap sistem pendidikan barat (kolonial), mendirikan perkumpulan yang dapat menjadi "wadah" pemberdayaan sosial ekonomi masyarakat melalui berbagai amalnya, dan mengakui bahwa agama tidak terbatas pada urusan "ritual". Kemudian atas desakan murid-muridnya KH. Ahmad Dahlan terpaksa mewujudkan cita-cita kaderisasinya dengan mendirikan lembaga keagamaan yang permanen. Maka, berdirilah organisasi Muhammadiyah di Yogyakarta pada 18 November 1912, dan juga mendirikan sebuah forum untuk pemudanya, Hizbul Wathan, dan sebuah forum untuk wanita. 'Aisyiyah (Nizar, 2005). Pendirian organisasi Muhammadiyyah oleh KH. Ahmad Dahlan semata-mata untuk menghidupkan kembali ajaran-ajaran murni agama Islam dan mengikuti serta merealisasikan segala kemauan agama Islam (Syarif, 2017).

Dengan basis massa perkotaan dari pedagang dan "sekolah" (berpendidikan), filosofi "modernisasi" tingkat mu'amalah (ijtihad dan tajdid) mendapat dukungan luas seiring dengan dorongan pembaruan Islam yang menyebar ke seluruh dunia pada pergantian tahun. Pada abad XX. KH. Ahmad Dahlan dianggap sebagai pemimpin nasionalis oleh kaum nasionalis terpelajar seperti Wahid Sudirohusodo dan KI Hajar Dewantoro. Gerakan KH. Ahmad Dahlan lahir dari kebijakan keterbukaan terhadap pendidikan kontemporer (sistem pemerintahan). KH. Ahmad Dahlan tidak begitu curiga terhadap pemerintah kolonial Belanda seperti halnya dia terhadap pemerintah kolonial Inggris. Memang, berbeda dengan sistem pesantren yang oleh pemerintah kolonial Belanda dianggap sebagai "sekolah liar", sekolah yang ia dirikan mendapat bantuan dari penguasa kolonial Belanda. 
4333 Refleksi Pemikiran Pembaharuan Pendidikan Islam Kh. Ahmad Dahlan terhadap Problematika Pendidikan Islam - Ghufran Hasyim Achmad

DOI: https://doi.org/10.31004/edukatif.v3i6.1319

Salah satu pesan KH. Ahmad Dahlan "Hidup Hidupilah Muhammadiyah, jangan mencari hidup dari Muhammadiyah" (etos kerja dan dedikasi): Muhammadiyah hendaknya menjadi sarana berjuang dan berdakwah. Muhammadiyah pun karena "dihidup-hidupi" menjadi kaya modal amal usaha. Sekarang ini. Mungkin banyak pengikut Muhammadiyah yang "mencari penghidupan" di Muhammadiyah. KH. Ahmad Dahlan terus-menerus menggunakan teks "Wajib" ketika melakukan perubahannya. Seiring dengan karyakarya klasik oleh para peneliti masa lalu, publikasi baru dibaca untuk perbandingan (Manaf, 2009).

KH. Ahmad Dahlan digambarkan sebagai seorang pejuang dan pahlawan terkait dengan gerakan dan pertempuran. Beliau merupakan pahlawan kemanusian yang mengorbankanjiwanya untuk pendidikan, sosial dan agama dalam kerangka kesadaran nasional yang kuat dan integral (Ni'mah, 2014). Sebagai apresiasi atas jasanya pada tahun 1961 diangkatnya menjadi pahlawan nasional melalui Keppres No. 657 dalam rangka meningkatkan kesadaran kebangsaan melalui reformasi dan pendidikan Islam. Dasar penetapan beliau sebagai pahlawan nasional yaitu, pertama, dengan banyak belajar dan berprestasi, KH. Ahmad Dahlan membuka jalan bagi umat Islam untuk menerima takdirnya sebagai bangsa kolonial. Kedua, Melalui organisasi Muhammadiyah yang ia ciptakan, ia mengajarkan kepada umatnya beberapa prinsip Islam yang hakiki. Atas dasar iman dan Islam, ajaran yang mendorong pertumbuhan, kecerdasan, dan kebaikan bagi masyarakat dan umat. Ketiga, Melalui organisasi Muhammadiyah, ia mempelopori amal sosial dan pendidikan yang sangat penting bagi kebangkitan dan kemajuan bangsa dalam semangat dan ajaran Islam. Keempat, Cabang organisasi perempuan Muhammadiyah (Aisyiyah) mempelopori akses perempuan Indonesia terhadap pendidikan (Nugroho, 2015).

KH. Ahmad Dahlan memiliki kecemasan dalam bidang Pendidikan, yakni manifestasi dari kemarahan dan ketidakpuasan mereka dengan penderitaan bangsa Indonesia oleh penjajahan yang dilakukan kolonial Belanda. Haji Fahrudin, mahasiswa KH. Ahmad Dahlan, menegaskan bahwa umat Islam pada pergantian abad kedua puluh mengalami stagnasi. Pada saat itu, komunitas Muslim di Indonesia tidak memiliki mercusuar keagungan dan kecemerlangan. Kehidupan Muslim sulit; ekonomi mereka tertinggal dan prospek mereka suram. KH. Ahmad Dahlan diberi tanggung jawab untuk mempertimbangkan dan memperbaiki kondisi umat Islam Indonesia. Upaya KH. Ahmad Dahlan dengan terbentuknya organisasi Muhammadiyah membuahkan hasil yang positif dalam memperbaiki kondisi umat islam di Indonesia.

\section{TUJUAN PENDIDIKAN PERSPEKTIF KH. AHMAD DAHLAN}

Dalam konteks pendidikan, KH. Ahmad Dahlan memiliki pandangan bahwa pendidikan merupakan komponen penting dalam menyelesaikan persoalan konstruksi sosial umat Islam yang terbangun atas pola pikir yang bersifat statis, serta mengubahnya menjadi pola pikir dinamis. Pendidikan harus didahulukan dari semua faktor lain dalam hal pembangunan manusia. Mereka harus dilatih untuk menjadi pintar, kritis, dan memiliki kemampuan analitis yang kuat untuk meramalkan dinamika kehidupan masa depan mereka. Kunci kemajuan muslimialah mengacu pada Al- Qur'an dan sunnah, membimbing orang-orang menuju pemahaman yang lengkap tentang ajaran Islam, dan menguasai berbagai bidang ilmiah. Pendidikan agama Islam harus bertujuan untuk mengembangkan pribadi muslim yang bermoral, alim, pluralistik dalam keyakinan agamanya, mampu memahami isu-isu ilmiah kontemporer, dan bersedia mengabdi dan membela masyarakat.

Terkait dengan tujuan pendidikan, KH. Ahmad Dahlan memandang pengembangan pribadi seseorang sebagai komponen penting dari tujuan pendidikan. Dia mengatakan bahwa tanpa kepribadian yang kuat, tidak ada yang bisa mencapai kebesaran di dunia ini atau di akhirat. Seseorang dengan kepribadian yang baik adalah seseorang yang mengikuti Al-Qur'an dan sunnah. Rasulullah adalah teladan, maka perlu untuk memperkenalkan siswa pada kehidupan Nabi selama proses pengembangan kepribadian mereka (Nata, 2005).

Diluar daripada pemikiran KH. Ahmad Dahlan yang menitik beratkan terhadap pembangunan atau infrastruktur, KH. Ahmad Dahlan berpendapat bahwa outcome learning pendidikan harus memiliki tujuan untuk mengembangkan setiap insan untuk memiliki karakteristik sebagai berikut: (1) akhlak mulia, yaitu 
4334 Refleksi Pemikiran Pembaharuan Pendidikan Islam Kh. Ahmad Dahlan terhadap Problematika Pendidikan Islam - Ghufran Hasyim Achmad

DOI: https://doi.org/10.31004/edukatif.v3i6.1319

ketakwaan beragama; (2) berwawasan luas, yang dapat didefinisikan sebagai bentuk ketekunan terhadap berbagai bidang ilmu yang dipelajari; dan (3) kemauan untuk berjuang serta manfaat demi kemajuan dan kemaslahatan umat.(Suharto, 2006)

K.H. Ahmad Dahlan memiliki beberapa kritik sosial dan intelektual yang diproyeksikan bagi sistem dan praktik Pendidikan di Indonesia saat itu. Bentuk dari kritik yang dilakukan oleh KH. Ahmad Dahlan bisa kita refleksikan dari usaha integrasi-interkoneksi yang dilakukan beliau terhadap materi dan metode pendidikan barat ke dalam sistem sekolah tradisional yang ada saat itu. KH. Ahmad Dahlan mampu menciptakan paradigma pendidikan Muhammadiyah (Suharto, 2006). Tujuan pedagogis adalah untuk mendamaikan tujuan pendidikan pesantren saat itu dengan pendidikan sekolah Belanda. Mencermati penyandang disabilitas, menurut KH. Ahmad Dahlan, tujuan pendidikan yang sempurna adalah untuk menghasilkan manusia yang memiliki penguasaan ilmu agama, materi, dan spiritual yang komprehensif.

KH. Ahmad Dahlan berpandangan bahwa Pendidikan Islam itu wajib memiliki misi menumbuh kembangkan muslim sejati yang memiliki ketakwaan kepada Tuhan sebagai abdullah dan khalifatullah dimuka bumi. Untuk mencapai visi tersebut, dibutuhkan suatu desain pendidikan Islam yang dapat mengintegrasikan berbagai macam pengetahuan yang ada, tanpa mendikotomikan pengetahuan itu sendiri dalam bentuk pengetahuan agama atau umum. Dalam mencapai tujuan tersebut, dibutuhkan internalisasi muatan metodologis yang integral dalam kurikulum pendidikan saat itu (Nizar, 2005). Oleh sebab itu, KH. Ahmad Dahlan optimis bahwa setiap manusai mampu mengemban amanah sebagai khalifah, karena beliau meyakini bahwa setiap manusia diberikan keistimewaan oleh Allah SWT. untuk berfikir (Ali et al., 2016).

\section{MATERI DAN METODE PEMBELAJARAN PERSPEKTIF KH. AHMAD DAHLAN}

Berdasarkan pemikiran KH. Ahmad Dahlan tersebut, Muhammadiyah mengintegrasikan pendidikan agama dan umum yang berlandaskan Al-Qur'an dan Hadits. Seiring dengan sastra Arab tradisional, sastra Arab saat ini dipelajari dalam hubungannya dengan pendidikan umum. Muhammadiyah mengadopsi sistem klasik model Barat dalam model ini, meninggalkan teknik weton dan sorogan dalam sistem tradisional. Muhammadiyah telah mengakui pentingnya RPP yang konsisten dan komprehensif untuk mengukur hasil belajar secara lebih efektif. Di lembaga pendidikan Muhammadiyah, interaksi antara pengajar dan siswa akan lebih akrab, bebas, dan demokratis (Suharto, 2006). Dalam desain pendidikan yang ditawarkan, KH. Ahmad Dahlan memiliki konsep Pendidikan Islam yang di implementasikan secara menurut kebutuhan peserta didik dari arus perkembangan zaman modern dan profesional. Pendidikan Islam harus inklusif, progresif, dan inventif untuk mencapai hal tersebut.

Metode pengajaran ini merupakan penekanan utama dari upaya KH. Ahmad Dahlan agar bisa bersaing dan sebanding dengan sekolah Belanda. Dia termotivasi oleh upaya agamawan Kristen untuk mendirikan sekolah. Menggunakan ini sebagai contoh, KH. Ahmad Dahlan mendirikan lembaga pendidikan Muhammadiyah untuk menyelenggarakan pendidikan agama wajib. Di Muhammadiyah, linguistik dan ilmu eksakta diajarkan sebagai topik yang menyeimbangkan ajaran agama. Dengan demikian, mempertahankan cita rasa Islam yang substansial dengan carayang berbeda dari sistem konvensional. Sebagai hasil dari usahanya, KH.Ahmad Dahlan mampu memodernisasi sekolah agama tradisional (Suharto, 2006).

Dalam hal reformasi kurikulum, KH. Ahmad Dahlan melakukan internalisasi dan interkoneksi antara materi Pendidikan umum dan agama yang secara integral masuk dalam kurikulum Pendidikan di Lembaga Pendidikan yang beliau dirikan; Muhammadiyah. Kemudian, dalam aspek lain seperti sarpras, KH. Ahmad Dahlan membangun sarpras yang dapat mendekatkan peserta didik untuk bersahabat dengan Al-Qur'an yang diimplementasikan dalam bentuk membaca, menulis, berhitung, dan membuat sketsa. Al-Qur'an dan Hadist mengandung materi sebagai berikut: ibadah, persamaan, peran tindakan dalam menentukan nasib seseorang, musyawarah, membuktikan kebenaran Al-Qur'an dan Hadist melalui akal, kerjasama antar agama dan budaya, 
4335 Refleksi Pemikiran Pembaharuan Pendidikan Islam Kh. Ahmad Dahlan terhadap Problematika Pendidikan Islam - Ghufran Hasyim Achmad

DOI: https://doi.org/10.31004/edukatif.v3i6.1319

kemajuan peradaban, hukum kausalitas, nafsu, dan kehendak, demokratisasi dan liberalisasi, kebebasan intelektual, ritme kehidupan, dan posisi manusia (Ramayulis \& Nizar, 2010).

Selain itu, KH. Ahmad Dahlan memulai studi sains secara langsung, berdasarkan ide-ide Al-Qur'an dan Hadits. Usaha untuk mewujudkannya tidaklah sederhana. Hal ini didasarkan pada konteks lembaga pendidikan konvensional pada saat itu, yang terutama bersifat keagamaan dan karenanya terbatas pada studi karya-karya kanonik mujtahid masa lalu, terutama Madzhab Syafi'I (Ramayulis \& Nizar, 2010).

Jenis ideologi ilmiah ini digunakan sebagai tameng oleh organisasi konvensional untuk melestarikan semantik statis dari epistemologi yang dihasilkan. Pendekatan seperti itu hanya akan melahirkan pikiran "sampah" yang tidak mampu memproses informasi yang diperoleh secara kritis, membuat mereka kurang mampu berkontribusi secara efektif dan kreatif untuk kemajuan masyarakat saat ini. Seperti terlihat, KH Ahmad Dahlan mengikuti langkah-langkah reformasi melalui pendirian pendidikan atau sekolah modern yang memadukan pengajaran agama dan sekuler. Beliau mempelopori konsep pendidikan, ini adalah momen transisi dan regenerasi karena mampu mengintegrasikan prinsip-prinsip Islam dan pengetahuan umum, agama dan kemajuan teknis, untuk menghasilkan generasi muslim yang bisa hidup atau bersaing dimasa yang akan datang tanpa memutuskan identitas mereka.

KH. Ahmad Dahlan mengadopsi pendekatan kontekstual melalui proses penyadaran dalam menyampaikan ilmu agama, bukan melalui proses tekstual. Menurut KH. Ahmad Dahlan, ajaran agama harus diajarkan sesuai dengan kemungkinan dan situasi yang ada (Nugroho, 2015). Hal ini ditunjukkan melalui kisah KH. Ahmad Dahlan dan murid-muridnya yang sedang mempelajari Surah Al-Maun. Kisah ini bermula dari murid-murid yang belajar Al-Qur'an bersama KH. Ahmad Dahlan merasa jenuh sebab ajaran dari Surah Al-Maun tidak terulang di sesi-sesi berikutnya. Saat mahasiswa protes, KH. Ahmad Dahlan bertanya apakah mereka ingat surat pendek itu. Saat siswa mengaku sudah hafal, KH. Ahmad Dahlan menanyakan apakah mereka telah memahami isi dan tujuannya, para siswa menanggapi bahwa mereka telah memahami isi dan tujuan surat tersebut. KH. Ahmad Dahlan kemudian menanyakan apakah siswa sudah menginternalisasi isi dan maksud surat tersebut. Mahasiswa mulai memahami alasan dan keadaan di balik keputusan KH. Ahmad Dahlan untuk tidak menyelesaikan kuliahnya (Mulkhan, 2010).

Menurut KH. Ahmad Dahlan, pemeluk Islam tidak boleh memanfaatkan ajarannya sebagai landasan dan pedoman hidup dan sampai diikuti. Menurut KH. Ahmad Dahlan, terlepas dari kualitas tujuan pertunjukan, jika tidak dilaksanakan, tidak akan dapat dicapai secara bersama-sama. Oleh karena itu KH. Ahmad Dahlan tidak secara terang-terangan memamerkan ayat-ayat Al-Qur'an, melainkan mengungkapkannya lebih lengkap melalui perbuatannya. Keberlakuan Surat Al-Ma'un ditunjukkan melalui pendirian panti asuhan dan perumahan bagi masyarakat berpenghasilan rendah (Nugroho, 2015).

Selain itu, KH. Ahmad Dahlan memilih metode ceramah. Ia tetap menjadi fasilitator utama proses pembelajaran dalam kapasitasnya sebagai guru. Hal ini cukup beralasan mengingat konteks sejarah dan dampak dari metode pengajaran ala pesantren. Sebagaimana diketahui, metode pendidikan bandongan dan sorogan diterapkan di pesantren pada saat itu. Sistem pendidikan disusun dengan cara tertentu. Dari kyai hingga santri, selain dari buku yang dibaca, kyai adalah satu-satunya sumber informasi. Kemungkinan besar, sistem dan metode seperti itu tidak memiliki aspek percakapan. KH.Ahmad Dahlan menggunakan paradigma "learning by doing" meskipun tidak ada penjelasan (learning by doing). Informasi yang disampaikan harus digunakan, karena ilmu dan amal saling terkait erat.

\section{PEMBAHARUAN SISTEM PENDIDIKAN}

Upaya yang dilakukan oleh KH. Ahmad Dahlan untuk memodernisasi metode perencanaan pendidikannya, yaitu penggantian sistem pesantren tradisional (salaf) dengan pesantren yang menggunakan sistem pendidikan modern yang sesuai dengan standar saat ini (pesantern modern). Upaya ini terlihat pada tumbuhnya pendidikan luar biasa, yaitu adopsi sistem pendidikan Barat. Cara tersebut dimodifikasi sehingga 
4336 Refleksi Pemikiran Pembaharuan Pendidikan Islam Kh. Ahmad Dahlan terhadap Problematika Pendidikan Islam - Ghufran Hasyim Achmad

DOI: https://doi.org/10.31004/edukatif.v3i6.1319

menggabungkan karakter nusantara dengan tetap berpegang pada prinsip-prinsip Islam (Kurniawan \& Mahrus, 2011).

Ada dua jenis model pendidikan: (a) model sekolah umum dan (b) model sekolah luar biasa. KH.Ahmad Dahlan mendirikan sekolah pertama yaitu sekolah dasar yang dimulai dengan pengajian. Murid laki-laki dan perempuan bersekolah di sekolah ini, yang dilengkapi dengan papan tulis dan kapur, tempat duduk, dan alatalat pembelajaran. Ini adalah pertama kalinya pendidikan dilaksanakan dengan cara menggabungkan gaya pengajaran pesantren dengan sistem sekolah barat. (b) Masjid, KH. Ahmad Dahlan mendirikan madrasah, sebuah pemerintahan agama yang meniru madrasah, di samping sekolah. Perbedaan utama antara sekolah adalah kurikulum, yang terdiri dari 60\% konten agama dan 40\% konten sekuler. Sementara itu, Muhammadiyah merevisi pendekatannya untuk berinteraksi dengan siswa selama proses pembelajaran. Metode pengajaran merupakan model pembaharuan yang menyatukan sistem pendidikan Barat dan pesantren, dimana mata kuliah diajarkan secara bersamaan kepada santriwan dan satriwati. Dikalangan masyarakat menganggap metode pendidikan ini asing dan sekolah kafir (Kurniawan \& Mahrus, 2011).

Bagi KH. Ahmad Dahlan, aspek terpenting dari kontribusi pendidikannya adalah pendidikan lintas agama. Kyai Sudjamenjelaskan bahwa, KH. Ahmad Dahlan mengajak siswa OSVIA Kristen untuk terlibat dalam kegiatan ekstrakurikuler pendidikan Islam yang terorganisir. Ini adalah kejadian yang sama sekali baru. KH. Ahmad Dahlan memungkinkan siswa non-Muslim untuk belajar tentang Islam tidak hanya melalui interaksi mereka dengan Muslim, tetapi juga melalui substansi ajarannya.

KH. Ahmad Dahlan memiliki kepribadian yang supel. Hubungannya melampaui Muslim hingga misionaris dan zending. KH. Ahmad Dahlan memiliki sejumlah perbedaan pendapat dengan mereka, tetapi hubungannya dengan para pemimpin agama Kristen tetap solid. KH. Ahmad Dahlan masih mengenakan sorban saat memasuki gereja, tanpa membuat dirinya tidak nyaman.

\section{REFLEKSI PEMIKIRAN DAN PERGERAKAN KH. AHMAD DAHLAN}

Problematika dalam dunia pendidikan memang sangat beragam. Mulai dari minimnya pemahaman yang ditanamkan kepada peserta didik terkait dengan keberagaman agama, materi pendidikan yang belum terintegrasi, serta minimnya penanaman nilai-nilai etika yang sesuai dengan ajaran Islam. Problematika terparah yang dihadapi oleh pendidikan Islam yaitu krisis moral spiritual masyarakat. Kondisi demikian berimplikasi kepada semakin berkurangnya kualitas pendidikan Islam. Sehingga banyak output dari lembaga pendidikan Islam masih gagap dengan perkembangan zaman dan bahkan memunculkan paradigm bahwa pendidikan Islam belum mampu merealisasikan pendidikan (Yuliasari, 2014).

Sebagai refleksi dari pemikiran dan pergerakan KH. Ahmad Dahlan, saat ini sekolah dan Universitas Muhammadiyah menyambut baik peserta didik muslim maupun non-muslim. Peserta didik non-muslim di lembaga pendidikan Muhammadiyah mendapatkan pengajaran agama yang sesuai dengan pandangan mereka dari para pengajar agama yang seagama. Ini termasuk pendidikan, yang sangat penting untuk mengembangkan interaksi antar agama dan menerima keragaman. Dari pemikiran ini kita dapat melihat peran pendidikan agama Islam melalui pendidikan lintas iman kita dapat menanamkan nilai-nilai multikultural seperti toleransi, demokrasi (Qolbi \& Tasman, 2021). Sistem tersebut seharusnya menjadi contoh bagi setiap lembaga pendidikan khususnya lembaga pendidikan Islam. Lembaga pendidikan Islam tidak boleh menolak non muslim yang mau belajar di lembaga tersebut. Dengan demikian setiap warga negara Indonesia memiliki hak untuk belajar apa dan dimana saja.

Pemikiran pemikiran KH. Ahmad Dahlan tentang wawasan kebangsaan dan keagamaan yang dinaungi dalam organisasi Muhammadiyah terus berkembang secara pesat dalam berbagai sosial maupun kegaamaan yang tentunya mengikuti dan menyesuaikan dengan perkembangan zaman. Muhamadiyah dengan purifikasinya memang banyak mengkritik keagamaan sebagai masyarakat NU. Seperti tahlilan dan ziarah kubur. Praktik keagamaan tersebut dinilai melanggar ajaran Islam atau bid'ah. Dalam beberapa sisi, kritik itu 
4337 Refleksi Pemikiran Pembaharuan Pendidikan Islam Kh. Ahmad Dahlan terhadap Problematika Pendidikan Islam - Ghufran Hasyim Achmad

DOI: https://doi.org/10.31004/edukatif.v3i6.1319

dapat dinilai relevan, namun sisi lain kritik tadi lebih mencerminkan eksistensi bid'ah. Tahlilan sebenarnya adalah perintah islam, sedangkan kumpul bersama dengan momen tertentu dalam bertahlilan, apakah suatu "agama" atau budaya dalam beragama karena ia menyangkut "cara" (yang selama tidak bertentangan dengan larangan agama, "tidak hanya begitu, tidak harus begitu", cara bisa dibenarkan. NU dengan tradisinya yang banyak melestarikan praktik keagamaan masyarakat tidak jarang juga cenderung "mengutamakan" tradisi tersebut. Sehingga sangat tradisional (dan mungkin sinkretik). Agar pertikaian bisa dieliminasi, masingmasing kecenderung purifikasi dalam Muhammadiyah dan tradisionalisme dalam NU dan Muhammadiyah juga harus ditempatkan secara porposional, sebatas sebagai persyarikatan atau jami'iyah, bukan ideologi Islam.

Pemikiran K.H. Ahmad Dahlan mengenai menyeimbangkan antara ilmu umum dan agama tentu sangat relevan terhadap pendidikan saat ini. Sebagaimana sekarang ini banyak lembaga pendidikan yang mengadopsi sistem pendidikan Islam modern sebagai pelengkap pendidikan pesantren. Dimana didalamnya diajarkan ilmu agama dan juga ilmu-ilmu umum yang diwadahi oleh sekolah madrasah dan sekolah umum. Kemudian didalamnya juga menekankan penggunaan bahasa asing yang akan memberikan ketrampilan berbahasa kepada peserta didik. Kemudian juga mayoritas sekolah sekarang dari Sekolah Dasar (SD) sampai perguruan tinggi menggunakan sistem education atau penggabungan laki-laki dan perempuan dalam menempuh pendidikan. Meskipun demikian, masih ada lembaga pendidikan Islam yang menggunakan sistem tradisional. Lembagalembaga tersebut hanya fokus mendalami ilmu agama, sehingga ilmu umum hampir tidak disentuh. Begitu juga sebaliknya, banyak lembaga pendidikan umum yang tidak menyeimbangkan ilmu umum dengan ilmu agama. Pemikiran KH. Ahmad Dahlan harus menjadi refleksi bagi lembaga pendidikan Islam dan umum, demi menyeimbangkan ilmu agama dan ilmu umum. Jika hal tersebut dapat terealisasi maka output dari setiap lembaga pendidikan akan kaya dengan ilmu pengetahuan yang integratif.

Perspektif KH. Ahmad Dahlan tentang pendidikan Islam saat ini adalah bagian integral dari tujuan dan kurikulum pendidikan Islam, sebagai konsekuensi dari keinginan KH. Ahmad Dahlan untuk memadukan komponen kognitif, emosional, dan psikomotorik. Selain itu, jalur pendidikan Islam saat ini tidak hanya membutuhkan kemampuan kognitif, emosional, dan psikomotorik, tetapi juga penanaman nilai-nilai positif dalam diri individu. Dan perspektif KH. Ahmad Dahlan terhadap pendidikan Islam banyak memiliki gagasan yang menekankan perlunya menanamkan kualitas pribadi, etika, dan moral kepada siswa. Pemikiran KH. Ahmad Dahlan menjadi kritik sekaligus sebagai refleksi bagi lembaga pendidikan Islam yang hanya mengedepankan komponen kognitif, emosional, dan psikomotorik. Sedangkan kualitas iman, etika, dan moral terkadang dikesampingkan. Fenomena ini dapat dilihat dari banyaknya tindakan amoral yang dilakukan oleh pelajar dari lembaga pendidikan Islam. Lembaga pendidikan harus mengedepankan nilai-nilai agama. Dengan demikian peserta didik akan memiliki jiwa serta kepribadian dengan tingkat religiusitas yang tinggi.

Proyeksi dari tujuan Pendidikan Islam modern yang digaungkan oleh KH. Ahmad Dahlan dapat kita proyeksikan dari outcome learning baru yang ingin dicapai, yakni "cendekiawan intelektual" yang didefinisikan sebagai seorang muslim yang memiliki keimanan yang teguh, keluasan ilmu, serta kekuatan jasmani dan rohani. Tujuan pendidikan KH. Ahmad Dahlan adalah untuk mengembangkan generasi Muslim dengan kepribadian yang kuat dan tidak rusak. Mereka adalah orang-orang yang memenuhi syarat agama, akal, dan tanggung jawab sosial. Pendidikan harus mengembangkan individu yang terhubung dengan komunitasnya dan sebagai khalifah yang memajukan negaranya. KH Ahmad Dahlan mengambil dua tindakan pada saat itu untuk mengintegrasikan dua sistem pendidikan: ia mulai mengajar agama di sekolah Belanda dan mendirikan sekolah yang dimana agama dan pengetahuan umum ada di dalamnya. Tindakan ini telah berkembang luas pada periode modern. Yang pertama telah diakomodasi oleh negara, sedangkan yang kedua telah dilakukan oleh berbagai lembaga pendidikan Islam. Namun, konsep model pendidikan integralistik KH. Ahmad Dahlan yang mampu menghasilkan cendekiawan-intelektual muslim masih terus digali. Sistem pendidikan integralistik ini sebenarnya merupakan jejak yang patut ditelusuri dalam konteks ruang dan waktu. 
4338 Refleksi Pemikiran Pembaharuan Pendidikan Islam Kh. Ahmad Dahlan terhadap Problematika Pendidikan Islam - Ghufran Hasyim Achmad

DOI: https://doi.org/10.31004/edukatif.v3i6.1319

Isu-isu teknis dalam pendidikan mungkin berkembang dalam menanggapi kemajuan penelitian (Nugroho, 2015).

\section{KESIMPULAN}

Pemikiran cemerlang dan pergerakan progresif dari KH. Ahmad Dahlan memiliki pengaruh besar bagi perkembangan pendidikan Islam khususnya di Indonesia. Pemikiran dan pergerakan beliau harus diadopsi oleh setiap lembaga pendidikan. Pemikiran dan pergerakan beliau menjadi refleksi dalam peningkatan kualitas lembaga pendidikan. Pembaharuan sistem, materi, metode dalam pendidikan harus terus dilakukan. Jika hal tersebut terealisasi maka output dari lembaga pendidikan Islam akan memiliki jiwa sosial, nasionalisme, serta religiusitas yang tinggi.

\section{DAFTAR PUSTAKA}

Ali, M., Kuntoro, S. A., \& Sutrisno, S. (2016). Pendidikan Berkemajuan: Refleksi Praktis Pendidikan Kh. Ahmad Dahlan. Jurnal Pembangunan Pendidikan: Fondasi Dan Aplikasi, 4(1), 43-58. Https://Doi.Org/10.21831/Jppfa.V4i1.7821

Amelia, T. F., \& Hudaidah, H. (2021). Pembaharuan Pendidikan Berdasarkan Pemikiran K. H. Ahmad Dahlan. Edukatif: Jurnal Ilmu Pendidikan, 3(2). Https://Doi.Org/10.31004/Edukatif.V3i2.333

Basri, H. (2009). Filsafat Pendidikan Islam. Pustaka Setia.

Hamzah, A. (2020). Metode Penelitian Kepustakaan Library Research. Literasi Nusantara.

Kurniawan, S., \& Mahrus, E. (2011). Jejak Pemikiran Tokoh Pendidikan Islam. Ar-Ruzz Media.

Manaf, A. (2009). 101 Jejak Tokoh Islam Indonesia. Nusantar.

Mu'thi, A., \& Marihandono, D. (2015). K.H. Ahmad Dahlan (1868-1923). Museum Kebangkitan Nasional.

Mulkhan, A. M. (2010). Jejak Pembaharuan Sosial Dan Kemanusian Kiai Ahmad Dahlan. Kompas.

Muvid, M. B. (2020). Filsafat Pendidikan Islam (Sebuah Tinjauan Dan Kajian Pendidikan Islam Beserta Pendidikan Tokoh Filsuf Muslim Dunia Dan Nusantara). Pustaka Pelajar.

Nata, A. (2005). Tokoh-Tokoh Pembaharuan Pendidikan Islam Di Indonesia. Pt Raja Grafindo.

Ni'mah, Z. A. (2014). Pemikiran Pendidikan Islam Perspektif Kh. Ahmad Dahlan Dan Kh. Hasyim Asy'ari. Didaktika Religia, 2(1).

Nizar, S. (2005). Filsafat Pendidikan Islam Historis Teoritis Dan Praktis. Ciputat Pers.

Nugroho, A. (2015). K.H. Ahmad Dahlan Biografi Singkat 1869-1923. Garasi.

Putra, D. W. (2018). Konsep Pendidikan Islam Dalam Perspektif Kh. Ahmad Dahlan. Tarlim: Jurnal Pendidikan Agama Islam, 1(2). Https://Doi.Org/10.32528/Tarlim.V1i2.1704

Qolbi, K. S., \& Tasman, H. (2021). Edukatif: Jurnal Ilmu Pendidikan Impelementasi Asas-Asas Pengembangan Kurikulum Terhadap Pengembangan Kurikulum Pendidikan Agama Islam. Jurnal Ilmu Pendidikan, 3(4), 1121132. Https://Doi.Org/10.31004/Edukatif.V3i4.511

Ramayulis, \& Nizar, S. (2010). Ensiklopedia Tokoh Pendidikan Islam (Mengeal Tokoh Pendidikan Islam Di Dunia Dan Indonesia). Quantum Teaching.

Suharto, T. (2006). Filsafat Pendidikan Islam: Menguatkan Epistemologi Islam Dalam Pendidikan. In Rose $\mathrm{Kr}$ (Ed.), Ae-Ruzz Media. Ar-Ruzz Media.

Syaifuddin, M. A., Anggraeni, H., Khotimah, P. C., \& Mahfud, C. (2019). Sejarah Sosial Pendidikan Islam Modern Di Muhammadiyah. $\quad$ Tadarus, $8(1) . \quad$ Http://Journal.Um- 
4339 Refleksi Pemikiran Pembaharuan Pendidikan Islam Kh. Ahmad Dahlan terhadap Problematika Pendidikan Islam - Ghufran Hasyim Achmad

DOI: https://doi.org/10.31004/edukatif.v3i6.1319

Surabaya.Ac.Id/Index.Php/Tadarus/Article/View/2649

Syarif, U. (2017). Gerakan Pembaruan Pendidikan Islam: Studi Komparasi Pergerakan Islam Indonesia Antara Syekh Ahmad Surkatiy Dan Kh Ahmad Dahlan. Reflektika, 12(1), 74-95. Https://Doi.Org/10.28944/Reflektika.V13i1.71

Yuliasari, P. (2014). Relevansi Konsep Pendidikan Islam Kh. Ahmad Dahlan Di Abad 21. As-Salam: Jurnal Studi Hukum Islam \& Pendidikan, 3(1), 45-64. Https://Doi.Org/10.51226/Assalam.V3i1.53 